\title{
Critical Success Factors for BIM Implementation in Construction Projects
}

\author{
A. M. Darwish ${ }^{1^{*}}$, M. M. Tantawy ${ }^{2}$, Emad Elbeltagi ${ }^{3}$ \\ ${ }^{1}$ Bachelor Degree in Civil Engineering 2002, Mansoura University, Egypt \\ ${ }^{2}$ Department of Civil Engineering, Faculty of Engineering, Mataria Branch, Helwan University, Egypt \\ ${ }^{3}$ Department of Civil Engineering, Faculty of Engineering, Mansoura University, Egypt
}

DOI: $10.36348 /$ sjce.2020.v04i09.006

| Received: 07.11.2020 | Accepted: 19.11.2020 | Published: 30.11 .2020

*Corresponding author: A. M. Darwish

Abstract

The advent of Building Information Modeling (BIM) offers new opportunities to further harness the efficiency of construction projects. Hence, to implement a BIM project in construction projects successfully without unforeseen confusion and troubles, the factors affecting the project's success must be identified and managed effectively. The research objectives are to identify the CSFs for enhancing BIM implementation and investigate the interrelationships among these CSFs. Fifty-one success factors are identified through literature review and a questionnaire survey is conducted among 345 participants. The results identified 15 factors as the most critical ones among the identified 51 factors, with the "coordination between all project parties"ranked the top. These fifteen significant factors have been grouped into an integrated structural framework that can help to enhance BIM implementation in construction projects. Also, this study developed a framework to measure the performance of BIM implementation which would help to follow the progress of BIM implementation along the project life cycle.

Keywords: Building Information Modeling (BIM), construction projects, factors, Implementation.

Copyright (C) 2020 The Author(s): This is an open-access article distributed under the terms of the Creative Commons Attribution 4.0 International License (CC BY-NC 4.0) which permits unrestricted use, distribution, and reproduction in any medium for non-commercial use provided the original author and source are credited.

\section{INTRODUCTION}

The Construction Industry in the Middle East is booming due to the growing population and the greater demand for infrastructure projects. There are currently 117 major projects that are ongoing in the region and to be completed by 2030 with a total cost of US\$1 trillion dollars [1]. Despite this, the governing delivery approach is the traditional one [2].

Building Information Modelling (BIM) can be claimed as a procedural and technological shift in the Architectural, Engineering and Construction (AEC) industry [1]. Improvements in the construction industry are necessary and BIM offers a way to bring about improvements. New economic imperatives demand new more efficient and effective methods of working. Many previous studies have identified the problems that permeate the building industry, and other studies have indicated the potential benefits of adopting BIM [3]. One of the reasons for the difficulties in managing construction projects, especially in the government sector due to the failure in determining the CSFs across project phases [4]. Hence, the successful adoption of BIM technology can be defined as vital but manageable
BIM-induced performance of an organization in critical areas. So, there is an urgent need to study CSFs for BIM implementation to improve the performance of construction projects.

\section{LITERATURE REVIEW}

Almost researches primarily focus on BIM implementation especially in developed countries such as the United States [5-10], the United Kingdom [11, 5, 12-16], Canada [17], France [18], Hong Kong [19-22] and Singapore [23, 24]. However, there is a little research on BIM implementation in developing countries especially in the Middle East region. Some studies are existed before 2018 limited to four countries: KSA [25-29], UAE [30, 31], Turkey [32, 33] and Iraq [34]. Moreover, previous studies concentrated on identifying the barriers and various challenges of BIM adoption rather than success factors $[35,36,25,6$, $37,1,38-43]$. In contrast, there is a little study that deals with the CSFs of BIM implementation in the developing countries before 2018 and are limited to four studies [30, 28, 34, 32]. Elhendawi [28] concentrated on raising BIM awareness; Barriers diminishes implementation of BIM in KSA, ways to overcome these barriers, BIM Benefits, and 
Methodology to implement BIM in KSA. Ahmed [30] investigated the CSFs of BIM but the study limited to the precast structures in the UAE's Construction Industry only also he missed many of the CSFs of BIM. Hamada et al., [34] discussed the Benefits of 4D/BIM in projects, the challenges of $4 \mathrm{D} / \mathrm{BIM}$ and they claimed that the CSFs of BIM in Iraq only is to engage the foreign companies with Iraqi companies in implementing more projects with BIM within the Iraqi construction industry. Ozorhon \& Karahan [32] focused on identifying the CSFs for the successful delivery of BIM in Architecture, Engineering, Construction and Owner-operated (AECO) organisations in Turkey. However, they research failed to identify CSFs for BIM projects, and weakness in the approach to identify the BIM-CSFs for the project while not linking the common factors with each other and study the relationship between them.

Therefore, after a broad review of previous studies and with low oil prices and lack of resources in the Middle East, there is a need to explore the CSFs for the implementation and adoption of BIM in the context of developing economies in the Middle East such as Saudi Arabia and Egypt. In this study, a total of 45 success factors have been identified from the previous studies In addition to 6 factors, they were added to the questionnaire after the initial review of $6 \mathrm{BIM}$ experts, thus the total number of factors studied was 51 , as listed in Table-1. These studies investigated only a few specific factors that enhanced BIM implementation in particular countries rather than studying all the 51 success factors comprehensively.

Table-1: Success factors to enhance BIM implementation from previous studies

\begin{tabular}{|c|c|c|}
\hline Code & Factor & Reference \\
\hline $\mathrm{C} 1$ & $\begin{array}{l}\text { Awareness level for BIM of the } \\
\text { industry }\end{array}$ & $\begin{array}{l}\text { (S. Ahmed, 2018; Azhar, 2011; C. T. Chan, 2014; Elhendawi, 2018; Gerges et } \\
\text { al., 2017; Khosrowshahi \& Arayici, 2012 [44]; Olawumi \& Chan, 2019; } \\
\text { Ozorhon \& Karahan, 2016; Shang \& Shen, 2014; Sodangi et al., 2018; Yaakob } \\
\text { et al., 2016) }\end{array}$ \\
\hline $\mathrm{C} 2$ & $\begin{array}{l}\text { Availability of information and } \\
\text { technology }\end{array}$ & $\begin{array}{l}\text { (Antwi-Afari et al., 2018; Azhar, 2011; Ning Gu \& London, 2010; } \\
\text { Khosrowshahi \& Arayici, 2012; Morlhon et al., 2014; Ozorhon \& Karahan, } \\
\text { 2016; Won et al., 2013) }\end{array}$ \\
\hline $\mathrm{C} 3$ & Training and development & $\begin{array}{l}\text { (M. A. Ahmed, 2017; S. Alhumayn et al., 2017; Y. Arayici, Onyenobi, TC and } \\
\text { Egbu, CO,et al, 2012; Chuck Eastman et al., 2011; Gerges et al., 2017; Hill, } \\
\text { 2014; Mohamed, 2018; Olawumi \& Chan, 2019; Ozorhon \& Karahan, 2016; } \\
\text { Bilal Succar et al., 2013; Won \& Lee, 2010; K. d. Wong \& Fan, 2013) }\end{array}$ \\
\hline $\mathrm{C} 4$ & Government's roles and supports. & $\begin{array}{l}\text { (S. Alhumayn et al., 2017; Y. Arayici, Onyenobi, TC and Egbu, CO,et al, 2012; } \\
\text { C. T. Chan, 2014; Eadie et al., 2013; Elhendawi, 2018; Omar, 2015; Ozorhon \& } \\
\text { Karahan, 2016; Porwal \& Hewage, 2013; M. A. D. Saleh, 2015; Wan } \\
\text { Mohammad et al., 2018; Won et al., 2013) }\end{array}$ \\
\hline $\mathrm{C} 5$ & $\begin{array}{l}\text { Availability of competencies and } \\
\text { experiences }\end{array}$ & $\begin{array}{l}\text { (Chien et al., } 2014 \text { [45]; Elhendawi, 2018; N. Gu et al., 2007; Ozorhon \& } \\
\text { Karahan, 2016; Bilal Succar et al., 2013; Won et al., 2013) }\end{array}$ \\
\hline C6 & Availability of financial resources & $\begin{array}{l}\text { (S. Alhumayn et al., 2017; Chuck Eastman et al., 2011; Hill, 2014; Liu et al., } \\
\text { 2010; Omar, 2015; Ozorhon \& Karahan, 2016; M. A. D. Saleh, 2015; Bilal } \\
\text { Succar et al., 2013; Won et al., 2013) }\end{array}$ \\
\hline C7 & Availability of qualified staff & $\begin{array}{l}\text { (S. Alhumayn et al., 2017; Y. Arayici et al., 2009; Y. Arayici, Onyenobi, TC and } \\
\text { Egbu, CO,et al, 2012; Chien et al., 2014; Ning Gu \& London, 2010; Ozorhon \& } \\
\text { Karahan, 2016; M. A. D. Saleh, 2015; Bilal Succar et al., 2013; Tsai et al., 2014; } \\
\text { Won et al., 2013) }\end{array}$ \\
\hline $\mathrm{C} 8$ & BIM adoption strategy & $\begin{array}{l}\text { (Khosrowshahi \& Arayici, 2012; Mehran, 2016; M. A. D. Saleh, 2015; Won et } \\
\text { al., 2013) }\end{array}$ \\
\hline C9 & Cultural change & (Elhendawi, 2018; Liu et al., 2010) \\
\hline $\mathrm{C} 10$ & Supportive organizational culture & $\begin{array}{l}\text { (Khosrowshahi \& Arayici, 2012; Olawumi \& Chan, 2019; Ozorhon \& Karahan, } \\
\text { 2016; Won \& Lee, 2010; Won et al., 2013) }\end{array}$ \\
\hline C11 & $\begin{array}{l}\text { Information and knowledge sharing } \\
\text { within the industry }\end{array}$ & $\begin{array}{l}\text { (Azhar, 2011; Elhendawi, 2018; Olawumi \& Chan, 2019; Ozorhon \& Karahan, } \\
\text { 2016) }\end{array}$ \\
\hline $\mathrm{C} 12$ & Client requirement and ownership & $\begin{array}{l}\text { (C. T. Chan, 2014; Olawumi \& Chan, 2019; Ozorhon \& Karahan, 2016; Bilal } \\
\text { Succar et al., 2013) }\end{array}$ \\
\hline $\mathrm{C} 13$ & $\begin{array}{l}\text { Coordination between all project } \\
\text { parties }\end{array}$ & $\begin{array}{l}\text { (S. Alhumayn et al., 2017; Y. Arayici et al., 2011; Azhar, 2011; C. Eastman et } \\
\text { al., 2008; Chuck Eastman et al., 2011; Hill, 2014; Khosrowshahi \& Arayici, } \\
\text { 2012; Ozorhon \& Karahan, 2016) }\end{array}$ \\
\hline $\mathrm{C} 14$ & Project size & $\begin{array}{l}\text { (Y. Arayici et al., 2011; Elmualim \& Gilder, 2014; Olawumi \& Chan, 2019; } \\
\text { Omar, 2015; Ozorhon \& Karahan, 2016) }\end{array}$ \\
\hline $\mathrm{C} 15$ & Continuous investment in BIM & (Z. Ding et al., 2015; M. A. D. Saleh, 2015) \\
\hline $\mathrm{C} 16$ & Consulting & $\begin{array}{l}\text { (Hwang \& Lim, 2012; Khosrowshahi \& Arayici, 2012; Ozorhon \& Karahan, } \\
\text { 2016) }\end{array}$ \\
\hline $\mathrm{C} 17$ & $\begin{array}{l}\text { Establishment of a model of good } \\
\text { practice for BIM and sustainability } \\
\text { implementation }\end{array}$ & $\begin{array}{l}\text { (Y. Arayici et al., 2009; C. T. Chan, 2014; Chien et al., 2014; Eadie et al., 2013; } \\
\text { Mehran, 2016; Mohamed, 2018; M. A. D. Saleh, 2015; B. Succar, 2009; Won et } \\
\text { al., 2013) }\end{array}$ \\
\hline
\end{tabular}




\begin{tabular}{|c|c|c|}
\hline $\mathrm{C} 18$ & Investment in BIM costs & (C. Eastman et al., 2008; Won \& Lee, 2010; Won et al., 2013) \\
\hline C19 & Learning curve & $\begin{array}{l}\text { (S. Ahmed, 2018; Azhar, 2011; C. Eastman et al., 2008; Shang \& Shen, 2014; } \\
\text { Won et al., 2013) }\end{array}$ \\
\hline $\mathrm{C} 20$ & Quality of BIM & (M. A. D. Saleh, 2015; Tsai et al., 2014; Won \& Lee, 2010) \\
\hline $\mathrm{C} 21$ & Pilot project & (Mohamed, 2018; M. A. D. Saleh, 2015; Won \& Lee, 2010) \\
\hline $\mathrm{C} 22$ & Competitive pressure & $\begin{array}{l}\text { (Azhar, 2011; Eadie et al., 2013; Elhendawi, 2018; Ning Gu \& London, 2010; } \\
\text { Liu et al., 2010) }\end{array}$ \\
\hline $\mathrm{C} 23$ & Performance metrics & (Won \& Lee, 2010, 2016; Yilmaz et al., 2019) \\
\hline $\mathrm{C} 24$ & Collaboration between all stakeholders & $\begin{array}{l}\text { (Y. Arayici et al., 2009; Chegu Badrinath \& Hsieh, 2018; Elhendawi, 2018; } \\
\text { Mohamed, 2018) }\end{array}$ \\
\hline $\mathrm{C} 25$ & BIM functions and features & (Won et al., 2013) \\
\hline $\mathrm{C} 26$ & The project manager and team & (Won \& Lee, 2010) \\
\hline $\mathrm{C} 27$ & IT capabilities technical support & $\begin{array}{l}\text { (M. A. Ahmed, 2017; Y. Arayici, Onyenobi, TC and Egbu, CO,et al, 2012; } \\
\text { Bender, 2010; Won \& Lee, 2010) }\end{array}$ \\
\hline $\mathrm{C} 28$ & Project delivery system like (IPD). & (Mohamed, 2018) \\
\hline $\mathrm{C} 29$ & $\begin{array}{l}\text { Change in the construction business } \\
\text { environment }\end{array}$ & (Mohamed, 2018) \\
\hline $\mathrm{C} 30$ & $\begin{array}{l}\text { Availability of appropriate software } \\
\text { and hardware tools }\end{array}$ & $\begin{array}{l}\text { (Azhar, 2011; Elhendawi, 2018; Ning Gu \& London, 2010; Olawumi \& Chan, } \\
\text { 2019) }\end{array}$ \\
\hline $\mathrm{C} 31$ & Perceived benefits from BIM to client & (Azhar, 2011; Elhendawi, 2018; Ning Gu \& London, 2010) \\
\hline $\mathrm{C} 32$ & BIM required by other project parties & (Elhendawi, 2018; M. A. D. Saleh, 2015) \\
\hline $\mathrm{C} 33$ & Collaboration with universities & (Elhendawi, 2018; M. A. D. Saleh, 2015) \\
\hline $\mathrm{C} 34$ & Safety into the construction process & (Z. Ding et al., 2015; Elhendawi, 2018; Omar, 2015; M. A. D. Saleh, 2015) \\
\hline $\mathrm{C} 35$ & Business Process Reengineering & $\begin{array}{l}\text { (Y. Arayici et al., 2011; Y. Arayici et al., 2009; Chuck Eastman et al., 2011; } \\
\text { Ning Gu \& London, 2010; Khosrowshahi \& Arayici, 2012; Tsai et al., 2014) }\end{array}$ \\
\hline $\mathrm{C} 36$ & $\begin{array}{l}\text { Providing better implementation of } \\
\text { lean construction, green sustainability } \\
\text { and integrated project delivery }\end{array}$ & (Antwi-Afari et al., 2018; Y. Arayici et al., 2011; Chuck Eastman et al., 2011) \\
\hline $\mathrm{C} 37$ & $\begin{array}{lll}\begin{array}{l}\text { Thermal energy } \\
\text { simulation }\end{array} & \text { analysis and } \\
\end{array}$ & (Antwi-Afari et al., 2018; Azhar, 2011) \\
\hline $\mathrm{C} 38$ & $\begin{array}{l}\text { Providing BIM models for off site } \\
\text { prefabrication }\end{array}$ & (Antwi-Afari et al., 2018; Azhar, 2011; Chuck Eastman et al., 2011) \\
\hline $\mathrm{C} 39$ & $\begin{array}{l}\text { Improved site layout, planning and site } \\
\text { safety }\end{array}$ & (Antwi-Afari et al., 2018) \\
\hline $\mathrm{C} 40$ & Experience level within the firm & $\begin{array}{l}\text { (Chien et al., 2014; N. Gu et al., 2007; Ozorhon \& Karahan, 2016; Won et al., } \\
\text { 2013) }\end{array}$ \\
\hline $\mathrm{C} 41$ & Appropriate legislation & $\begin{array}{l}\text { (Y. Arayici et al., 2009; C. T. Chan, 2014; Chien et al., 2014; Eadie et al., 2013; } \\
\text { Mohamed, 2018; Olawumi \& Chan, 2019; Ozorhon \& Karahan, 2016; B. } \\
\text { Succar, 2009; Won et al., 2013) }\end{array}$ \\
\hline $\mathrm{C} 42$ & $\begin{array}{l}\text { Increased involvement of project } \\
\text { stakeholders in green projects }\end{array}$ & (Olawumi \& Chan, 2019) \\
\hline $\mathrm{C} 43$ & $\begin{array}{l}\text { Clarity in requirements and measures } \\
\text { for achieving sustainable projects }\end{array}$ & (Olawumi \& Chan, 2019) \\
\hline $\mathrm{C} 44$ & $\begin{array}{l}\begin{array}{l}\text { Client satisfaction level on BIM } \\
\text { projects }\end{array} \\
\end{array}$ & (Olawumi \& Chan, 2019) \\
\hline $\mathrm{C} 45$ & $\begin{array}{l}\text { Availability of BIM and sustainability } \\
\text { databases }\end{array}$ & (Olawumi \& Chan, 2019) \\
\hline $\mathrm{C} 46$ & $\begin{array}{l}\text { Shared risks, liability, and rewards } \\
\text { among project } \\
\text { stakeholders }\end{array}$ & from BIM experts \\
\hline $\mathrm{C} 47$ & $\begin{array}{l}\text { Number of subcontractors experienced } \\
\text { with BIM projects }\end{array}$ & from BIM experts \\
\hline $\mathrm{C} 48$ & Early involvement of project teams & from BIM experts \\
\hline $\mathrm{C} 49$ & $\begin{array}{l}\begin{array}{l}\text { Technical support from software } \\
\text { vendors }\end{array} \\
\end{array}$ & from BIM experts \\
\hline C50 & Open - source software development & from BIM experts \\
\hline C51 & $\begin{array}{l}\text { Make all the BIM programs work on } \\
\text { an open source such as the IFC (for } \\
\text { easy import and export without losing } \\
\text { any data) }\end{array}$ & from BIM experts \\
\hline
\end{tabular}




\section{RESEARCH METHODOLOGY}

The research methodology is summarized in the following steps:

- Examination of CSFs for the implementation of BIM for construction projects from previous studies.

- A questionnaire was developed with support from the previous studies included all determining factors which affect the success of BIM implementation in construction projects

- Initially, the questionnaire was distributed to 6 BIM-experts to review the questionnaire before final distribution, based on the expert review, six factors were added to the questionnaire, making a total of 51 factors.

- Data analysis for the questionnaire results and ranking the factors to determine the significant factors which have the highest impact on the success of BIM implementation in construction projects.

- Components of the proposed framework for enhancing BIM implementation were ranked based on their normalized values as per the below (1: Normalized value $=($ mean - minimum mean $) /$ (maximum mean - minimum mean) .............. (1)

- The factors have been included in their respective groups (Framework components) and ranked according to normalization calculations to reflect the significant factors which affect the BIM implementation.

- Statistical analyse for CSFs of BIM implementation with their respective groups.

- Based on the results of the analysis, a simple framework is proposed as a guide for enhancing BIM implementation.
DATA COLLECTION AND ANALYSIS

The Sample size is calculated as the following equation: SS $($ Sample Size $)=\frac{z^{2} \times p(1-p)}{e^{2}}$

Where $\mathrm{z}=1.64$ at $95 \%$ confidence, $\mathrm{P}=0.20$, e $=0.80$. SS $($ Sample Size $)=\frac{1.64^{2} \times 0.2(1-0.2)}{0.08^{2}}=68$

However, the actual collected sample size was used for this study is 345

\section{Respondents' Profile}

The profile of the respondents is presented in Table- 2 where $80.9 \%$ of the respondents are Egyptians and $3.8 \%$ are Saudis. While $64.6 \%$ of the respondent worked in Saudi Arabia, $24.1 \%$ worked in Egypt. In terms of respondent educational level, most of the respondents $(71.90 \%)$ educational level is B.Sc., $22 \%$ MSc. Besides, about $72.0 \%$ of the sample had high experience greater than 10 years in the construction field; therefore, their opinions are highly appreciated. Regarding the Respondents' project size, it is noticed that the majority of the participants $(41.70 \%)$ the worked in project less than $\$ 50$ million value, while $14.8 \%$ from $\$ 50-100$ million Also, regarding the respondents' knowledge of BIM, (156) $45.2 \%$ selected No and finish the questionnaire because they do not have enough knowledge to continue. However, (189) $54.8 \%$ indicated that they knew BIM. Moreover, only $32.5 \%$ of respondents from Egypt had an awareness of BIM while $61 \%$ of Saudi respondents were aware of BIM, indicating that there is still a lack of awareness about BIM Knowledge, especially in Egypt. Besides, $60.8 \%$ expected that there would be increase in using of BIM in the future. This result is in-line with the literature in KSA. However, in other countries, the literature expected that BIM becomes a mandate from the governments.

Table-2: Respondent's characteristics

\begin{tabular}{|l|l|l|l|}
\hline Category & Characteristic & Frequency & Percentage (\%) \\
\hline Nationality & Egypt & 279 & 80.9 \\
\cline { 2 - 4 } & KSA & 13 & 3.8 \\
\cline { 2 - 4 } & Syria & 13 & 3.8 \\
\cline { 2 - 4 } & Turkey & 2 & 0.6 \\
\cline { 2 - 4 } & Other & 38 & 11.0 \\
\hline \multirow{5}{*}{ Workplace } & Egypt & 83 & 24.1 \\
\cline { 2 - 4 } & KSA & 223 & 64.6 \\
\cline { 2 - 4 } & Qatar & 7 & 2.0 \\
\cline { 2 - 4 } & Kuwait & 8 & 2.3 \\
\cline { 2 - 4 } & Turkey & 2 & 0.6 \\
\cline { 2 - 4 } & UAE & 7 & 2.0 \\
\cline { 2 - 4 } & Other & 15 & 4.3 \\
\hline Education Level & BSc & 248 & 71.9 \\
\cline { 2 - 4 } & MSc & 76 & 22.0 \\
\cline { 2 - 4 } & PhD & 6 & 1.7 \\
\cline { 2 - 4 } & Other & 15 & 4.3 \\
\cline { 2 - 4 } & Total & 345 & 100.0 \\
\hline
\end{tabular}




\begin{tabular}{|c|c|c|c|}
\hline \multirow[t]{6}{*}{ Experience } & Less than 1 year & 15 & 4.3 \\
\hline & $1-5$ years & 32 & 9.3 \\
\hline & $5-10$ years & 49 & 14.2 \\
\hline & $10-15$ years & 66 & 19.1 \\
\hline & $15-20$ years & 112 & 32.5 \\
\hline & More than 20 years & 71 & 20.6 \\
\hline \multirow[t]{6}{*}{ Number of Employees } & Less than 20 & 71 & 20.6 \\
\hline & $20-50$ & 44 & 12.8 \\
\hline & $50-100$ & 39 & 11.3 \\
\hline & $100-150$ & 23 & 6.7 \\
\hline & $150-200$ & 15 & 4.3 \\
\hline & More than 200 & 153 & 44.3 \\
\hline \multirow[t]{6}{*}{ Project size } & Less than 50 million & 144 & 41.7 \\
\hline & $50-100$ million & 51 & 14.8 \\
\hline & 100-200 million & 48 & 13.9 \\
\hline & 200-500 million & 36 & 10.4 \\
\hline & 500M-1 Billion & 25 & 7.2 \\
\hline & More than 1 Billion & 41 & 11.9 \\
\hline \multirow[t]{5}{*}{ Company Category } & Owner & 58 & 16.8 \\
\hline & Consultant & 85 & 24.6 \\
\hline & Contractor & 134 & 38.8 \\
\hline & PMO & 10 & 2.9 \\
\hline & Other & 58 & 16.8 \\
\hline \multirow[t]{5}{*}{ Source of knowledge in BIM } & Study and practical experience & 51 & 14.8 \\
\hline & Scientific background & 15 & 4.3 \\
\hline & Training courses & 35 & 10.1 \\
\hline & Self learning & 88 & 25.5 \\
\hline & Nothing & 156 & 45.2 \\
\hline \multirow[t]{5}{*}{ Future of BIM } & Not using BIM & 11 & 5.8 \\
\hline & Increase using BIM & 115 & 60.8 \\
\hline & Pressure from upper Management to use BIM & 19 & 10.1 \\
\hline & Pressure from the government to use BIM & 23 & 12.2 \\
\hline & Other & 21 & 11.1 \\
\hline
\end{tabular}

The following analysis is performed for the collected survey results:

- Analysis of CSFs of BIM implementation and conducting rreliability analysis.

- Rank the factors by calculating their nnormalization value.

- Analyze the CSFs of BIM implementation with their respective groups by calculating Person correlation, to find out their correlation strength, Chi-Square test and conducting ANOVA analysis, to find out the effect of independent variables (Source of knowledge in BIM) on dependent variables (the significant factors which BIM implementation).

\section{Reliability Analysis}

Reliability is the overall consistency of a measure (Elhendawi, 2018). Cronbach's alpha test was performed to check the reliability of questions or items resulted in a vlue equals to 0.983 , which is much higher than the threshold of 0.70 (Robinson et al., 2013), indicating internal consistency of the items and high data reliability.

\section{Factors Ranking}

The ranking was made in two steps: Ranking of the success factors and ranking for the component of a framework for enhancing BIM implementation, as shown in Table-3. The success factors were ranked based on their normalized value, ranging from 1.00 to 0.522 . The results showed that 15 out of the 51 success factors received normalised values equal to or greater than 0.50 (in red colour), indicating that these 15 factors are CSFs for enhancing BIM implementation in construction projects. Furthermore, "CF12" Coordination between all project parties ranked top, implying that the Coordination between all project parties would be the most efficient driving force for enhancing BIM implementation in construction projects.

From the previous studies, several groups were identified that could form a framework to help for enhancing BIM implementation in construction projects. These groups were placed within a question in the questionnaire to monitor the responses of the participants and identify the most important groups in the order that can help for enhancing BIM implementation. 


\section{These groups were divided as follows:}

1-(Group no 1).

It is concerned with project coordination and cooperation between all stakeholders and project participants, as well as disseminating and sharing information among team members

2-(Group no 2).

It is concerned with Project resource (Project team \&Organization, Stakeholder skills \&Competencies, BIM technology).

3-(Group no 3).

It is concerned with Project life cycle stage (Planning, Design, construction, Handover, Operation and maintenance stage). Also concerned with BIM adoption strategy and Establishment of a model of good practice for BIM during the project life cycle.

4-(Group no 4).

It is concerned with Processes (Standardization, User Involvement).

5-(Group no 5).

It is concerned with Business model

\section{6-(Group no 6).}

It is concerned with Legal Issue (Ownership, Commitment) as per shown in Table the previous six groups were ranked based on their normalized value, ranging from 0.999 to 0.001 . The results showed that 3 out of the six groups received normalized values equal to or greater than 0.50 (in red color), indicating that these three groups are the most important groups and can be components of a framework for enhancing BIM implementation in construction projects. Furthermore, (G1) Project coordination \& collaboration ranked top, implying that Project coordination \& collaboration would be the most efficient driving force component of a framework for enhancing BIM implementation in construction projects.

Refer to Table-4, the main component of a framework for BIM implementation are the following:

1. Project coordination \& collaboration (Group no 1).

2. Project resource (Project team \&Organization, Stakeholder skills \&Competencies, BIM technology) (Group no 2).

3. Project life cycle stage (Planning, Design, construction, Handover, Operation and maintenance stage) (Group no 3).

Table-3: Ranking of the success factors to enhance BIM implementation

\begin{tabular}{|c|c|c|c|c|c|c|}
\hline Code & Key Factors & $\mathbf{N}$ & Mean & $\begin{array}{l}\text { Std. } \\
\text { Deviation }\end{array}$ & Ranke & $\begin{array}{l}\text { Normali } \\
\text { zation }\end{array}$ \\
\hline CF12 & Coordination between all project parties & 189 & 4.159 & 0.867 & 1.00 & 1.000 \\
\hline CF2 & Training and development & 189 & 4.143 & 0.992 & 2.00 & 0.978 \\
\hline $\mathrm{CF} 1$ & Awareness level for BIM of the industry & 189 & 3.947 & 0.977 & 3.00 & 0.706 \\
\hline CF24 & BIM functions and features & 189 & 3.942 & 0.924 & 4.00 & 0.698 \\
\hline CF23 & Collaboration between all stakeholders & 189 & 3.931 & 0.917 & 5.00 & 0.684 \\
\hline CF30 & Perceived benefits from BIM to client & 189 & 3.915 & 1.088 & 6.00 & 0.662 \\
\hline CF4 & Availability of competencies and experiences & 189 & 3.905 & 0.918 & 7.00 & 0.647 \\
\hline CF16 & $\begin{array}{l}\text { Establishment of a model of good practice for BIM and } \\
\text { sustainability implementation }\end{array}$ & 189 & 3.905 & 0.995 & 8.00 & 0.647 \\
\hline CF6 & Availability of qualified staff & 189 & 3.868 & 0.994 & 9.00 & 0.595 \\
\hline CF51 & $\begin{array}{l}\text { Make all the BIM programs work on an open source such as the } \\
\text { IFC (for easy import and export without losing any data) }\end{array}$ & 189 & 3.856 & 1.042 & 10.00 & 0.580 \\
\hline CF11 & Client requirement and ownership & 189 & 3.847 & 1.001 & 11.00 & 0.566 \\
\hline $\mathrm{CF} 29$ & Availability of appropriate software and hardware tools & 189 & 3.847 & 1.043 & 12.00 & 0.566 \\
\hline CF10 & Information and knowledge sharing within the industry & 189 & 3.820 & 0.962 & 13.00 & 0.529 \\
\hline CF7 & BIM adoption strategy & 189 & 3.820 & 0.978 & 14.00 & 0.529 \\
\hline CF13 & Project size & 189 & 3.815 & 1.063 & 15.00 & 0.522 \\
\hline CF3 & Government's roles and supports & 189 & 3.799 & 1.053 & 16.00 & 0.500 \\
\hline CF31 & BIM required by other project parties & 189 & 3.799 & 0.979 & 17.00 & 0.500 \\
\hline CF44 & Availability of BIM and sustainability databases & 189 & 3.794 & 0.948 & 18.00 & 0.493 \\
\hline CF19 & Quality of BIM & 189 & 3.788 & 0.977 & 19.00 & 0.485 \\
\hline $\mathrm{CF} 25$ & The project manager and team & 189 & 3.772 & 1.003 & 20.00 & 0.463 \\
\hline $\mathrm{CF} 22$ & Performance metrics & 189 & 3.767 & 0.904 & 21.00 & 0.456 \\
\hline CF14 & Continuous investment in BIM & 189 & 3.767 & 0.983 & 22.00 & 0.456 \\
\hline CF39 & Experience level within the firm & 189 & 3.746 & 0.978 & 23.00 & 0.426 \\
\hline CF5 & Availability of financial resources & 189 & 3.741 & 0.985 & 24.00 & 0.419 \\
\hline CF35 & $\begin{array}{l}\text { Providing a better implementation of lean construction, green } \\
\text { sustainability, and integrated project delivery }\end{array}$ & 189 & 3.730 & 1.045 & 25.00 & 0.404 \\
\hline CF26 & IT capabilities technical support & 189 & 3.720 & 1.052 & 26.00 & 0.390 \\
\hline CF9 & Supportive organizational culture & 189 & 3.714 & 0.947 & 27.00 & 0.382 \\
\hline CF43 & Client satisfaction level on BIM projects & 189 & 3.709 & 1.044 & 28.00 & 0.375 \\
\hline $\mathrm{CF} 48$ & Early involvement of project teams & 189 & 3.709 & 0.987 & 29.00 & 0.375 \\
\hline CF50 & Open - source software development & 189 & 3.693 & 1.047 & 30.00 & 0.353 \\
\hline
\end{tabular}




\begin{tabular}{|l|l|l|l|l|l|l|}
\hline CF15 & Consulting & 189 & 3.693 & 0.935 & 31.00 & 0.353 \\
\hline CF38 & Improved site layout, planning and site safety & 189 & 3.683 & 1.003 & 32.00 & 0.338 \\
\hline CF49 & Technical support from software vendors & 189 & 3.677 & 1.003 & 33.00 & 0.331 \\
\hline CF37 & Providing BIM models for off site prefabrication & 189 & 3.667 & 1.021 & 34.00 & 0.316 \\
\hline CF17 & Investment in BIM costs & 189 & 3.651 & 0.884 & 35.00 & 0.294 \\
\hline CF41 & Increased involvement of project stakeholders in green projects & 189 & 3.651 & 1.003 & 36.00 & 0.294 \\
\hline CF18 & Learning curve & 189 & 3.646 & 0.949 & 37.00 & 0.287 \\
\hline CF20 & Pilot project & 189 & 3.646 & 0.903 & 38.00 & 0.287 \\
\hline CF40 & Appropriate legislation & 189 & 3.630 & 0.962 & 39.00 & 0.265 \\
\hline CF27 & Project delivery system like (IPD) & 189 & 3.624 & 1.022 & 40.00 & 0.257 \\
\hline CF33 & Safety into the construction process & 189 & 3.614 & 1.049 & 41.00 & 0.243 \\
\hline CF32 & Collaboration with universities & 189 & 3.614 & 1.074 & 42.00 & 0.243 \\
\hline CF45 & Increased research in the industry and academia & 189 & 3.608 & 1.003 & 43.00 & 0.235 \\
\hline CF42 & $\begin{array}{l}\text { Clarity in requirements and measures for achieving sustainable } \\
\text { projects }\end{array}$ & 189 & 3.593 & 0.994 & 44.00 & 0.213 \\
\hline CF21 & Competitive pressure & 189 & 3.582 & 0.962 & 45.00 & 0.199 \\
\hline CF46 & Shared risks, liability, and rewards among project stakeholders & 189 & 3.571 & 1.053 & 46.00 & 0.184 \\
\hline CF28 & Change in the construction business environment & 189 & 3.561 & 0.985 & 47.00 & 0.169 \\
\hline CF8 & Cultural changes & 189 & 3.556 & 0.953 & 48.00 & 0.162 \\
\hline CF34 & Business Process Reengineering & 189 & 3.550 & 1.039 & 49.00 & 0.155 \\
\hline CF47 & Number of subcontractors experienced with BIM projects & 189 & 3.508 & 1.085 & 50.00 & 0.096 \\
\hline CF36 & Thermal energy analysis and simulation & 189 & 3.439 & 1.007 & 51.00 & 0.000 \\
\hline
\end{tabular}

Table-4: Ranking for a component of a framework for enhance BIM implementation

\begin{tabular}{|l|l|l|l|l|l|l|}
\hline No. & Component of a framework & N & Mean & $\begin{array}{l}\text { Std. } \\
\text { Deviation }\end{array}$ & $\begin{array}{l}\text { Ranke } \\
\text { zation }\end{array}$ \\
\hline G1 & Project coordination \& collaboration & 189 & 4.048 & 1.033 & 1.00 & $\mathbf{0 . 9 9 9}$ \\
\hline G2 & $\begin{array}{l}\text { Project resource (Project team \&Organization, Stakeholder skills } \\
\text { \&Competencies, BIM technology) }\end{array}$ & 189 & 3.989 & 0.934 & 2.00 & $\mathbf{0 . 8 8 6}$ \\
\hline G3 & $\begin{array}{l}\text { Project life cycle stage (Planning, Design, construction, Handover, } \\
\text { Operation and maintenance stage) }\end{array}$ & 189 & 3.857 & 0.954 & 3.00 & $\mathbf{0 . 6 2 9}$ \\
\hline G4 & Processes (Standardization, User Involvement) & 189 & 3.693 & 0.906 & 5.00 & 0.310 \\
\hline G5 & Business model & 189 & 3.783 & 0.951 & 4.00 & 0.485 \\
\hline G6 & Legal Issue (Ownership, Commitment) & 189 & 3.534 & 0.981 & 6.00 & 0.001 \\
\hline
\end{tabular}

\section{Groups Significant Factors}

The factors are included in their respective groups and ranked according to normalization calculations to reflect the significant factors which affect the BIM implementation.
Group no. 1: Project coordination \& collaboration

According to the normalization calculations, coordination between all project parties is ranked the first factor in Project coordination \& collaboration with a value of 1.00 as shown in Table.

Table-5: Rank of factors influencing (Project coordination \& collaboration)

\begin{tabular}{|l|l|l|l|}
\hline No. & Key Factors & Normalization & Ranke \\
\hline CF12 & Coordination between all project parties & 1.000 & 1.00 \\
\hline CF23 & Collaboration between all stakeholders & 0.684 & 2.00 \\
\hline CF30 & Perceived benefits from BIM to client & 0.662 & 3.00 \\
\hline CF51 & $\begin{array}{l}\text { Make all the BIM programs work on an open source such as the } \\
\text { IFC (for easy import and export without losing any data) }\end{array}$ & 0.580 & 4.00 \\
\hline CF10 & Information and knowledge sharing within the industry & 0.529 & 5.00 \\
\hline
\end{tabular}

Group no. 2: Project resource (Project team \&Organization, Stakeholder skills \& Competencies, BIM technology)
According to the normalization calculations, training and development is ranked the first factor in Project resource with a normalized value of 0.978 as shown in Table. 
Table-6: Rank of factors influencing Project resource (Project team \& Organization, Stakeholder skills \&Competencies, BIM technology)

\begin{tabular}{|l|l|l|l|}
\hline No. & Key Factors & Normalization & Ranke \\
\hline CF2 & Training and development & 0.978 & 1.00 \\
\hline CF1 & Awareness level for BIM of the industry & 0.706 & 2.00 \\
\hline CF24 & BIM functions and features & 0.698 & 3.00 \\
\hline CF4 & Availability of competencies and experiences & 0.647 & 4.00 \\
\hline CF6 & Availability of qualified staff & 0.595 & 5.00 \\
\hline CF11 & Client requirement and ownership & 0.566 & 6.00 \\
\hline CF29 & Availability of appropriate software and hardware tools & 0.566 & 7.00 \\
\hline CF13 & Project size & 0.522 & 8.00 \\
\hline
\end{tabular}

Group no. 3: Rank of factors influencing Project life cycle stage (Planning, Design, construction, Handover, Operation and maintenance stage)

As shown in Table-7 the normalization value of factor (Establishment of a model of good practice for
BIM and sustainability) was 0.647 indicating that it is more important than the second factor (BIM adoption strategy).

Table-7: Project life cycle stage (Planning, Design, construction, Handover, Operation and maintenance stage)

\begin{tabular}{|l|l|l|l|}
\hline No. & Key Factors & Normalization & Ranke \\
\hline CF16 & Establishment of a model of good practice for BIM and sustainability implementation & 0.647 & 1.00 \\
\hline CF7 & BIM adoption strategy & 0.529 & 2.00 \\
\hline
\end{tabular}

\section{Statistical Analysis}

Many data analysis methods used in this research includes: Chi-Square Test to configure the relation between the independent variables (workplace, project size, years of experiences, Company Category and Nationality),Pearson correlation coefficient to examine the relationship among the success factors and between framework and its components (Groups), Analysis of Variance (ANOVA) it is used to study the effect of one independent factor with more than two parameters or more on dependent variables.

Pearson correlation: Pearson correlation test had been conducted on three levels as below:

1. Pearson Correlation Values between the 15 significant factors that had the high rank as presented in Table.

2. Pearson Correlation Values for the 15 significant factors and their groups.

3. Pearson correlation value between the proposed framework and its components (Groups) Figure-1.

The Pearson Correlation test results showed that: most of the fifteen significant factors and its groups are related to each other with strong or very strong relations, all groups and framework are correlated each other with very strong relation and showing that the structural framework is justifiable and logical which demonstrating the reliability of the information that has been obtained from the questionnaire and the seriousness of respondents in answering questions of the questionnaire, and the questionnaire had achieved its aim.

\section{Analysis of Variance (ANOVA)}

ANOVA test is conducted to study whether there are any significant differences between Means, it is used to study the effect of one independent factor or more on dependent variables, for this study One-Way ANOVA it is used to examine the effect of independent factors (Source of knowledge in BIM) on the Framework and its components (Groups that contain the 15 significant factors which affect for enhancing BIM implementation Figure-1 Error! Reference source not found, to proceed with (One- Way ANOVA) analysis, the results concluded that: There are no statistically significant differences between Means of this variable effect according to independent factor (Source of knowledge in BIM). 


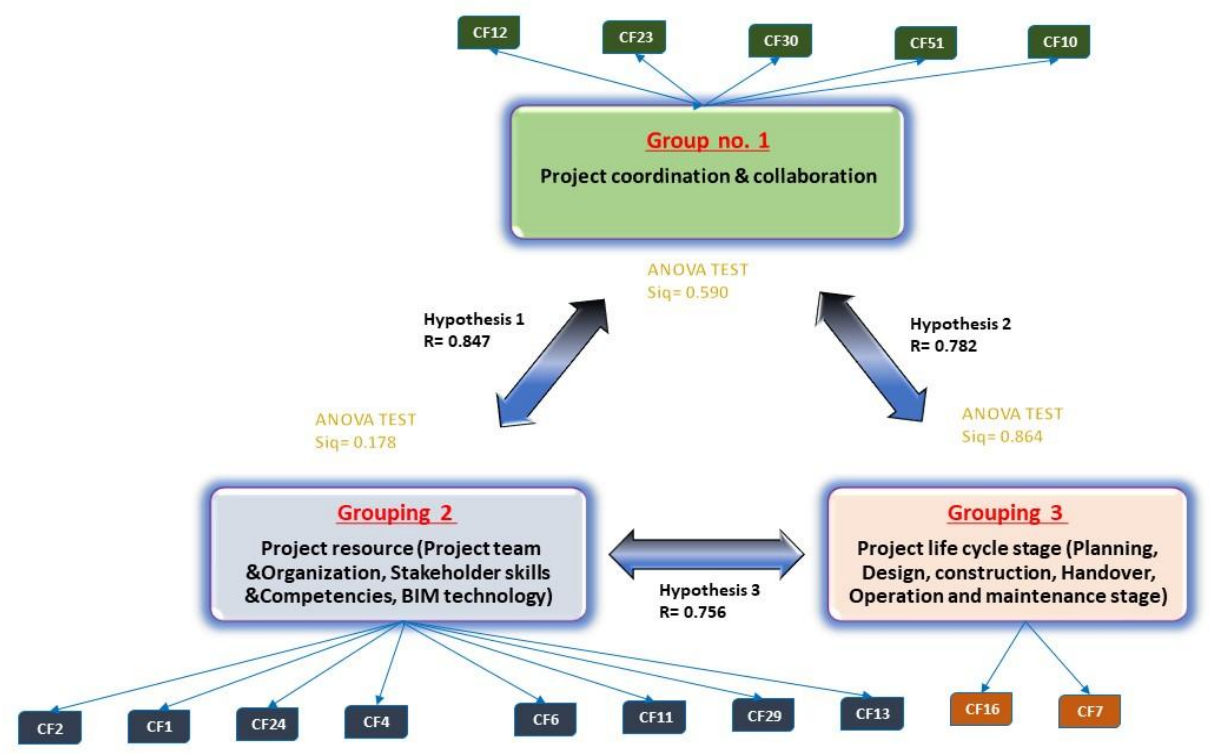

Fig-1: Framework for enhancing BIM implementation with correlation and ANOVA test value

A Proposal Form for Measuring (Performance Complete \%) For BIM Implementation

As a result, from this study, the gained data is used here to produce a form could be used by site management team to measure the performance percent for BIM implementation on site as periodically report. Regarding to the results which obtained from the study, factors which affect BIM implementation in construction projects are being ranked according to normalized index values, 15 significant factors are the most important factors in between all factors, these factors to be placed into a sheet to be watched and evaluated periodically on site, the factors are weighted relative to its normalized value, the total percentage $100 \%$ is distributed according to every factor weight, presents the weigh for the 15 significant factors. Table gives an example for a monthly report for performance complete percentage for this month, it depends on previous factors weights, and proposed Performance Weight percentage for every factor.

Table-8: Fifteen factors weight according to Normalization value

\begin{tabular}{|l|l|l|l|l|}
\hline No. & Key Factors & Normalization & Mean & $\begin{array}{l}\text { Factor } \\
\text { Weight } \%\end{array}$ \\
\hline 1 & Coordination between all project parties & 1.000 & 4.159 & $\mathbf{7 . 0 8}$ \\
\hline 2 & Training and development & 0.978 & 4.143 & $\mathbf{7 . 0 6}$ \\
\hline 3 & Awareness level for BIM of the industry & 0.706 & 3.947 & $\mathbf{6 . 7 2}$ \\
\hline 4 & BIM functions and features & 0.698 & 3.942 & $\mathbf{6 . 7 1}$ \\
\hline 5 & Collaboration between all stakeholders & 0.684 & 3.931 & $\mathbf{6 . 6 9}$ \\
\hline 6 & Perceived benefits from BIM to client & 0.662 & 3.915 & $\mathbf{6 . 6 7}$ \\
\hline 7 & Availability of competencies and experiences & 0.647 & $\mathbf{6 . 6 5}$ \\
\hline 8 & $\begin{array}{l}\text { Establishment of a model of good practice for BIM and } \\
\text { sustainability implementation }\end{array}$ & 0.647 & 3.905 & $\mathbf{6 . 6 5}$ \\
\hline 9 & Availability of qualified staff & 0.595 & 3.868 & $\mathbf{6 . 5 9}$ \\
\hline 10 & $\begin{array}{l}\text { Make all the BIM programs work on an open source such as } \\
\text { the IFC (for easy import and export without losing any data) }\end{array}$ & 0.580 & 3.856 & $\mathbf{6 . 5 7}$ \\
\hline 11 & Client requirement and ownership & 0.566 & & $\mathbf{6 . 5 5}$ \\
\hline 12 & Availability of appropriate software and hardware tools & 0.566 & 3.847 & $\mathbf{6 . 5 5}$ \\
\hline 13 & Information and knowledge sharing within the industry & 0.529 & 3.847 & $\mathbf{6 . 5 1}$ \\
\hline 14 & BIM adoption strategy & 0.529 & 3.820 & $\mathbf{6 . 5 1}$ \\
\hline 15 & Project size & 0.522 & 3.815 & $\mathbf{6 . 5 0}$ \\
\hline Total Sum & 9.908 & $\mathbf{1 0 0 . 0 0}$ \\
\hline
\end{tabular}

From Table, Total performance complete percentage value for this example is $73.65 \%$, this template could be used from any site parties even the contractor or the consultant or the owner, it is a helpful tool to follow and improve BIM implementation in building construction sites. 
Table-9: Template form for measuring Performance complete \% for BIM implementation

\begin{tabular}{|c|c|c|c|c|}
\hline \multicolumn{2}{|c|}{ Company Logo } & 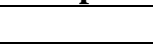 & \multicolumn{2}{|c|}{ Project Name: ---------------------- } \\
\hline \multicolumn{5}{|c|}{ Performance complete \% for BIM implementation Monthly Report Date: 16-6-2019 } \\
\hline No. & Key Factors & $\begin{array}{l}\text { Factor } \\
\text { Weight \% }\end{array}$ & $\begin{array}{l}\text { Performance } \\
\text { complete } \%\end{array}$ & $\begin{array}{l}\text { Performanc } \\
\text { e Weight \% }\end{array}$ \\
\hline 1 & Coordination between all project parties & 7.08 & 83.00 & $5.88 \%$ \\
\hline 2 & Training and development & 7.06 & 75.00 & $5.29 \%$ \\
\hline 3 & Awareness level for BIM of the industry & 6.72 & 65.00 & $4.37 \%$ \\
\hline 4 & BIM functions and features & 6.71 & 73.00 & $4.90 \%$ \\
\hline 5 & Collaboration between all stakeholders & 6.69 & 81.00 & $5.42 \%$ \\
\hline 6 & Perceived benefits from BIM to client & 6.67 & 82.00 & $5.47 \%$ \\
\hline 7 & Availability of competencies and experiences & 6.65 & 61.00 & $4.06 \%$ \\
\hline 8 & $\begin{array}{l}\text { Establishment of a model of good practice for BIM and } \\
\text { sustainability implementation }\end{array}$ & 6.65 & 52.00 & $3.46 \%$ \\
\hline 9 & Availability of qualified staff & 6.59 & 71.00 & $4.68 \%$ \\
\hline 10 & $\begin{array}{l}\text { Make all the BIM programs work on an open source such as } \\
\text { the IFC (for easy import and export without losing any data) }\end{array}$ & 6.57 & 0.00 & $0.00 \%$ \\
\hline 11 & Client requirement and ownership & 6.55 & 95.00 & $6.22 \%$ \\
\hline 12 & Availability of appropriate software and hardware tools & 6.55 & 87.00 & $5.70 \%$ \\
\hline 13 & Information and knowledge sharing within the industry & 6.51 & 95.00 & $6.18 \%$ \\
\hline 14 & BIM adoption strategy & 6.51 & 90.00 & $5.86 \%$ \\
\hline 15 & Project size & 6.50 & 95.00 & $6.17 \%$ \\
\hline \multicolumn{2}{|c|}{ Total Sum } & $\mathbf{1 0 0 . 0 0}$ & & $73.65 \%$ \\
\hline
\end{tabular}

\section{CONCLUSIONS}

The objective of this research was to define and establish the critical factors for BIM implementation that lead to project success. This study investigates all possible factors through a structured questionnaire. The questionnaire was distributed to many Middle Eastern countries, and most of the responses were from Saudi Arabia and Egypt. Fifty-one factors were identified from the literature. After collecting responses and conducting analysis it is concluded that; there are fifteen significant factors which have high rank more than 0.50. Moreover, (CF12) Coordination between all project parties ranked top, implying that the Coordination between all project parties would be the most efficient driving force for enhancing BIM implementation in construction projects. These fifteen significant factors have been included in their respective groups and ranked according to normalization calculations to reflect the significant factors which affect the BIM implementation. After conducting correlation analysis between all factors, between framework and its components (Groups), it is concluded that: most of the fifteen significant factors and its groups are related to each other with strong or very strong relations, all groups and framework are correlated each other with very strong relation and showing that the structural framework is justifiable and logical which demonstrating the reliability of the information that has been obtained from the questionnaire and the seriousness of respondents in answering questions of the questionnaire, and the questionnaire had achieved its aim.

There are no statistically significant differences between Means of this variable effect according to independent factor (Source of knowledge in BIM). Showing that the selection of the 15 critical factors was agreed upon by all sources of expertise, whether practical experience, scientific study, training courses or self-education. A simple Framework model is suggested in the study as a guide for enhancing BIM implementation. Another tool produced in this study, a Template form for measuring Performance for BIM implementation. This template presented to guide site management to quantify and to calculate the performance of BIM implementation across the project life cycle.

\section{ACKNOWLEDGEMENTS}

The authors would like to acknowledge the support provided by all professors supervising the research and all respondents from the various companies/institutions that made this research possible.

\section{REFERENCES}

1. Gerges, M., Austin, S., Mayouf, M., Ahiakwo, O, Jaeger, M., Saad, A., \& Gohary, T.-E. (2017). An investigation into the implementation of Building Information Modeling in the Middle East. Journal of Information Technology in Construction (ITcon), 22(1), 1-15.

2. Abou Rached, A., Basile, M., \& El Masri, H. (2014). Gastric leaks post sleeve gastrectomy: review of its prevention and management. World Journal of Gastroenterology: WJG, 20(38), 13904.

3. Coates, P. (2013). Nature: Western attitudes since ancient times. John Wiley \& Sons.

4. Takim, L. (2004). From conversion to conversation: Interfaith dialogue in post 9-11 America. The Muslim World, 94(3), 343.

5. Antwi-Afari, M. F., Li, H., Pärn, E. A., \& Edwards, D. J. (2018). Critical success factors for implementing building information modelling 
(BIM): A longitudinal review. Automation in Construction, $\quad$ 91, 100-110. doi:https://doi.org/10.1016/j.autcon.2018.03.010

6. Azhar, S. (2011). Building Information Modeling (BIM): Trends, Benefits ,Risks, and Challenges for the AEC Industry. Leadership and Management in Engineering, 11(3), 241-252. doi:doi:10.1061/(ASCE)LM.1943-5630.0000127

7. Hao, W., \& Xianhai, M. (2018). BIM-Based Knowledge Management in Construction Projects. International Journal of Information Technology Project Management (IJITPM), 9(2), 20-37. doi:10.4018/IJITPM.2018040102

8. Hill, M. (2014). The Business Value of BIM for Construction in Global Markets. In: McGraw Hill Construction, Bedford MA, United States.

9. Kuehmeier, J. C. (2008). Building information modeling and its impact on design and construction firms. University of Florida,

10. Langar, S., \& Pearce, A. (2014). State of adoption for building information modeling (BIM) in the southeastern United States. Paper presented at the 50th ASC Annual International Conference Proceedings.

11. Aleksander, W. (2016). Enhancing Facility Management through BIM 6D. Retrieved from bHeriot-Watt University, Riccarton Campus, Edinburgh EH14 4AS, Scotland, UK:

12. Arayici, Y., Khosrowshahi, Y., Ponting, A. M., \& Mihindu, S. (2009). Proc. of the 5th International Conference on Construction in the 21st Century (CITC-V-2009) (Vol. null).

13. Construction, M. H. (2010). The business value of BIM in Europe: Getting building information modelling to the bottom line the united kingdom, France and Germany. Smart Market Report, 1-50 .

14. Eadie, R., Browne, M., Odeyinka, H., McKeown, C., \& McNiff, S. (2013). BIM implementation throughout the UK construction project lifecycle: An analysis. Automation in Construction, 36, 145151.

15. Khosrowshahi, F., \& Arayici, Y. (2012). Roadmap for implementation of BIM in the UK construction industry. Engineering, Construction and Architectural Management.

16. Shang, Z., \& Shen, Z. (2014). Critical Success Factors (CSFs) of BIM Implementation for Collaboration based on System Analysis. In Computing in Civil and Building Engineering (2014) (pp. 1441-1448).

17. Morlhon, R., Pellerin, R., \& Bourgault, M. (2014). Building Information Modeling implementation through maturity evaluation and Critical Success Factors management. Procedia Technology, 16, 1126-1134.

18. Benjamin. (2013). Impacts of Building Information Modelling (BIM) on Project Management in the French Construction Industry. Retrieved from Birmingham.
19. Cheung, E., Chan, A. P., Lam, P. T., Chan, D. W., \& Ke, Y. (2012). A comparative study of critical success factors for public private partnerships (PPP) between Mainland China and the Hong Kong Special Administrative Region. Facilities, 30(13/14), 647-666.

20. Olawumi, T. O., \& Chan, D. W. (2019). Critical success factors for implementing building information modeling and sustainability practices in construction projects: A Delphi survey. Sustainable Development.

21. Weisheng Lu , G. Q. H. (2011). Scenarios for applying RFID technology in construction project management. Retrieved from Hong Kong:

22. Wong, K.-d. A., Wong, F. K., \& Nadeem, A. (2011). Building information modelling for tertiary construction education in Hong Kong. Journal of information technology in construction .

23. Hwang, B. G., \& Lim, E. S. J. (2012). Critical success factors for key project players and objectives: Case study of Singapore. Journal of Construction Engineering and Management, 139(2), 204-215.

24. Liao, L., \& Teo, E. A. L. (2017). Critical success factors for enhancing the building information modelling implementation in building projects in Singapore. Journal of Civil Engineering and Management, 23(8), 1029-1044.

25. Alhumayn, S., Chinyio, E., \& Ndekugri, I. (2017). The Barriers And Strategies Of Implementing Bim In Saudi Arabia. WIT Transactions on The Built Environment, 169, 55-67.

26. Alhumayn, S. A. (2018). Developing a framework for BIM implementation in the Saudi Arabian construction industry. In.

27. Almuntaser, T., Sanni-Anibire, M. O., \& Hassanain, M. A. (2018). Adoption and implementation of BIM-case study of a Saudi Arabian AEC firm. International Journal of Managing Projects in Business, 11(3), 608.624-

28. Elhendawi, A. I. N. (2018). Methodology for BIM implementation in KSA in AEC industry. ( Master of Science MSc in Construction Project Management), Edinburgh Napier University, UK.

29. Sodangi, M., Salman, A. F., \& Saleem, M. (2 (018 Building Information Modeling: Awareness Across the Subcontracting Sector of Saudi Arabian Construction Industry. Arabian Journal for Science and Engineering, 43(4), 1807-1816.

30. Ahmed, M. A. (2017). A Study on the Critical Success Factors using BIM for Precast Structures in the UAE's Construction Industry. The British University in Dubai (BUiD),

31. Omar, H. S. (2015). Solutions for the UAE architecture, engineering, and construction (AEC) industry to mandate building information modeling (BIM). The British University in Dubai (BUiD).

32. Ozorhon, B., \& Karahan, U. (2016). Critical success factors of building information modeling 
implementation. Journal of management in engineering, 33(3), 04016054.

33. Yilmaz, G ,.Akcamete, A., \& Demirors, O. (2019). An Assessment of BIM-CAREM Against the Selected BIM Capability Assessment Models. In Advances in Informatics and Computing in Civil and Construction Engineering (pp. 387-395): Springer.

34. Hamada, H. M., Haron, A., Zakiria, Z \& ,.Humada, A. M. (2017). Factor Affecting of BIM Technique in the Construction Firms in Iraq. MATEC Web Conf., 103, 03003.

35. Abubakar, M., Ibrahim, Y., Kado, D., \& Bala, K. (2014). Contractors' perception of the factors affecting Building Information Modelling (BIM) adoption in the Nigerian Construction Industry. In Computing in Civil and Building Engineering (2014) (pp. 167-17.(8

36. Ahmed, S. (2018). Barriers to Implementation of Building Information Modeling (BIM) to the Construction Industry: A Review. Journal of Civil Engineering and Construction, 7(2), 107-113.

37. Chan, C. T. (2014). Barriers of implementing BIM in construction industry from the designers' perspective: A Hong Kong experience. Journal of System and Management Sciences, 4(2), 24-40.

38. Imoudu, E. W. (2016). Factors Affecting Building Information Modelling Adoption by Malaysian Consultants and Contractors. Universiti Teknologi Malaysia,

39. Kiani, I., \& Ghomi, S .K. (2013). The Barriers and Implementation of Building Information Modeling
(BIM) based on Integrated Project Delivery (IPD) In the Construction Industry. In: Author Profiles for This Publication at: https://www. researchgate. net/publication/272789025.

40. Kiviniemi, A., \& Codinhoto, R. (2014). Challenges in the implementation of BIM for FM-Case Manchester Town Hall complex. In Computing in Civil and Building Engineering (2014) (665-672).

41. Reza Hosseini, M., Linda, E., Tivendal, A., \& Nicholas, C. (2015). Barriers to adoption of building information modeling (BIM) in Iran: Preliminary results. Australia.

42. Matarneh, R., \& Hamed, S. (2017). Barriers to the Adoption of Building Information Modeling in the Jordanian Building Industry. Open Journal of Civil Engineering, 7(03), 325.

43. Saleh, M. A. D. (2015). Barriers and Driving Factors for Implementing Building Information Modelling (BIM) in Libya. Eastern Mediterranean University (EMU)-Doğu Akdeniz Üniversitesi (DAÜ).

44. Khosrowshahi, F., \& Arayici, Y. (2012). Roadmap for implementation of BIM in the UK construction industry. Engineering, Construction and Architectural Management, 19(6), 610-635.

45. Chien, K. F., Wu, Z. H., \& Huang, S. C. (2014). Identifying and assessing critical risk factors for BIM projects: Empirical study. Automation in Construction, 45, 1-15. 